\title{
A global renewable energy system - A modelling exercise in ETSAP/TIAM
}

\author{
Balyk, Olexandr; Føyn, Tullik Helene Ystanes; Karlsson, Kenneth Bernard
}

Publication date:

2010

Link back to DTU Orbit

Citation (APA):

Balyk, O. (Author), Føyn, T. H. Y. (Author), \& Karlsson, K. B. (Author). (2010). A global renewable energy system - A modelling exercise in ETSAP/TIAM. Sound/Visual production (digital)

\section{General rights}

Copyright and moral rights for the publications made accessible in the public portal are retained by the authors and/or other copyright owners and it is a condition of accessing publications that users recognise and abide by the legal requirements associated with these rights.

- Users may download and print one copy of any publication from the public portal for the purpose of private study or research.

- You may not further distribute the material or use it for any profit-making activity or commercial gain

- You may freely distribute the URL identifying the publication in the public portal

If you believe that this document breaches copyright please contact us providing details, and we will remove access to the work immediately and investigate your claim. 


\section{A global renewable energy system - A modelling exercise in ETSAP/TIAM}

Olexandr Balyk, T. Helene Ystanes Føyn and Kenneth B. Karlsson

DTU Climate Centre, Risø DTU

TERI-ETSAP workshop

22. January 2010

New Delhi, India

Risø DTU

National Laboratory for Sustainable Energy

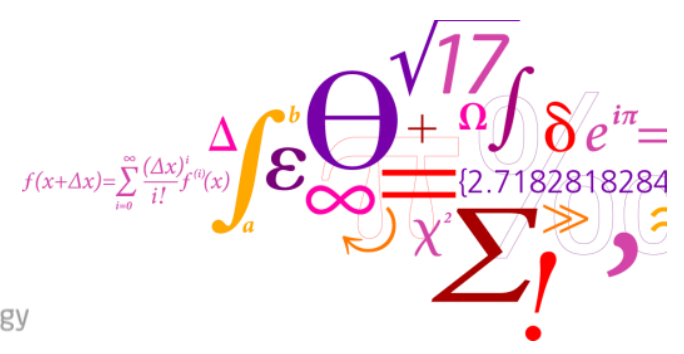

\section{Aim and background}

- New group working with TIMES/TIAM

- Test the ETSAP-TIAM global energy system model

- How far it can take us towards a global $100 \%$ renewable energy system with the existing model database?

- Where do we meet limits in global resources and data available in the model? 


\section{TIAM - TIMES Integrated Assessment Model}

\section{Growth assumptions (relative)}

TIAM-15R, version September2008
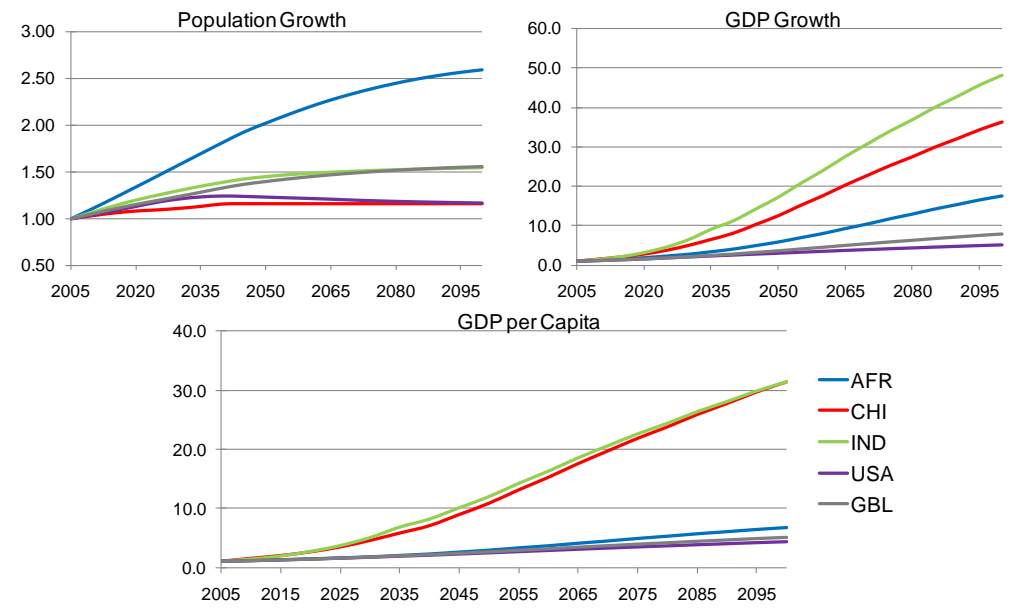

$4 \quad$ Risø DTU, Technical University of Denmark

A global renewable energy system... 22/01/2010 


\section{Growth assumptions (absolute)}

\section{TIAM-15R, version September2008}
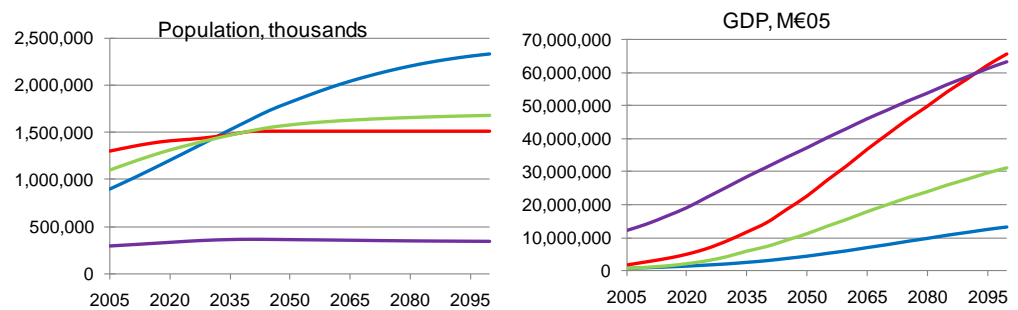

$\begin{array}{lllllll}2005 & 2020 & 2035 & 2050 & 2065 & 2080 & 2095\end{array}$

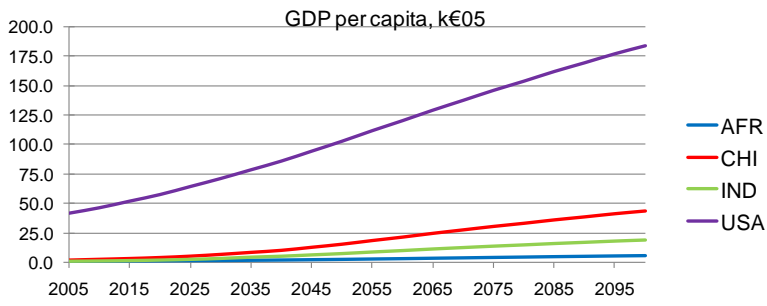

\section{Forcing renewables into the global energy system}

\section{Scenarios:}

- Reference scenario

- Standard assumptions, policy-free

- Alternative scenario I: $\mathrm{CO}_{2} \mathrm{ppm}$

- $\mathrm{CO}_{2}$ concentration in atmosphere restricted to $400 \mathrm{ppm}$

- Alternative scenario II: global $\mathrm{CO}_{2}$ e price

- The price for GHG emission fixed to 400 Euro per tonne $\mathrm{CO}_{2} \mathrm{e}$ 


\section{$\mathrm{CO}_{2}$ concentration and system costs}
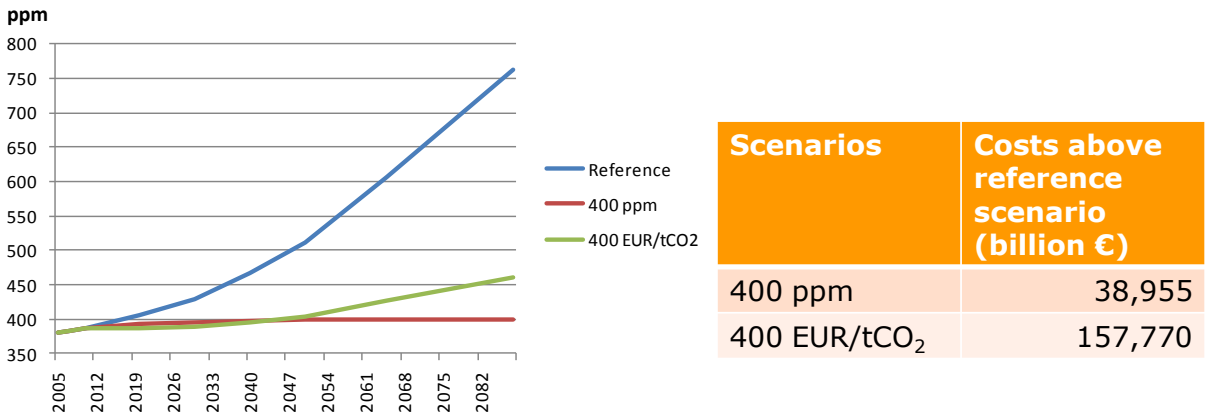

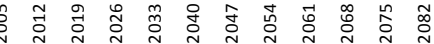

$400 \mathrm{EUR} / \mathrm{tCO}_{2}$

157,770

\section{Power generation}

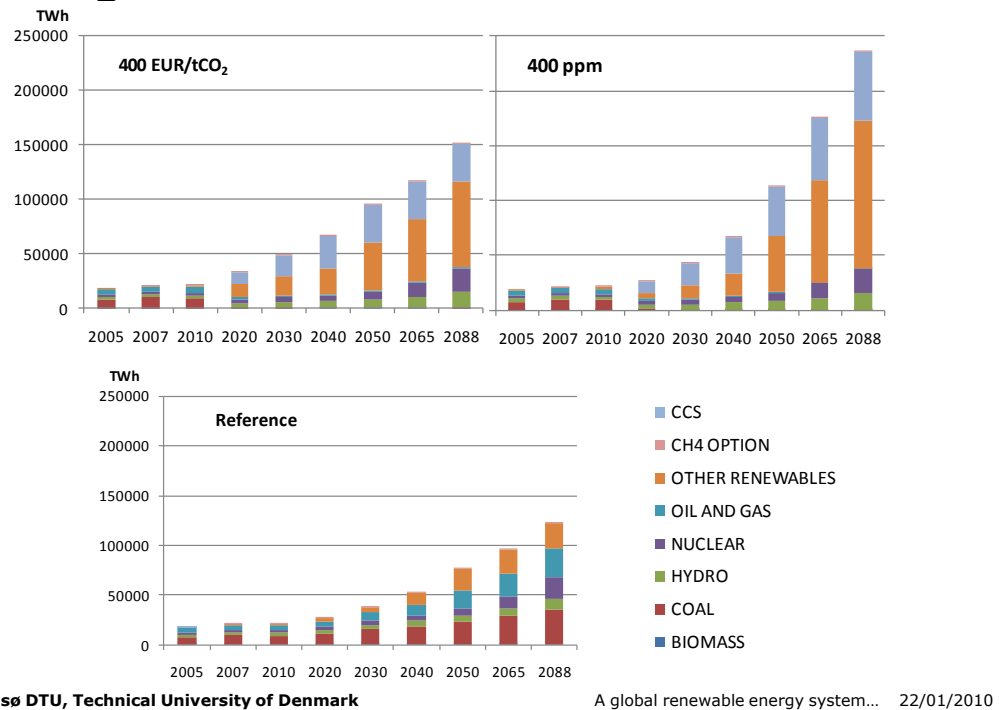




\section{Power generation (cont.)}

- Large increase in power generation in alternative scenarios

- Fuel switching in industry

- Synergies between CCS and methanol - methanol penetrates in road transport

\section{Final energy consumption}

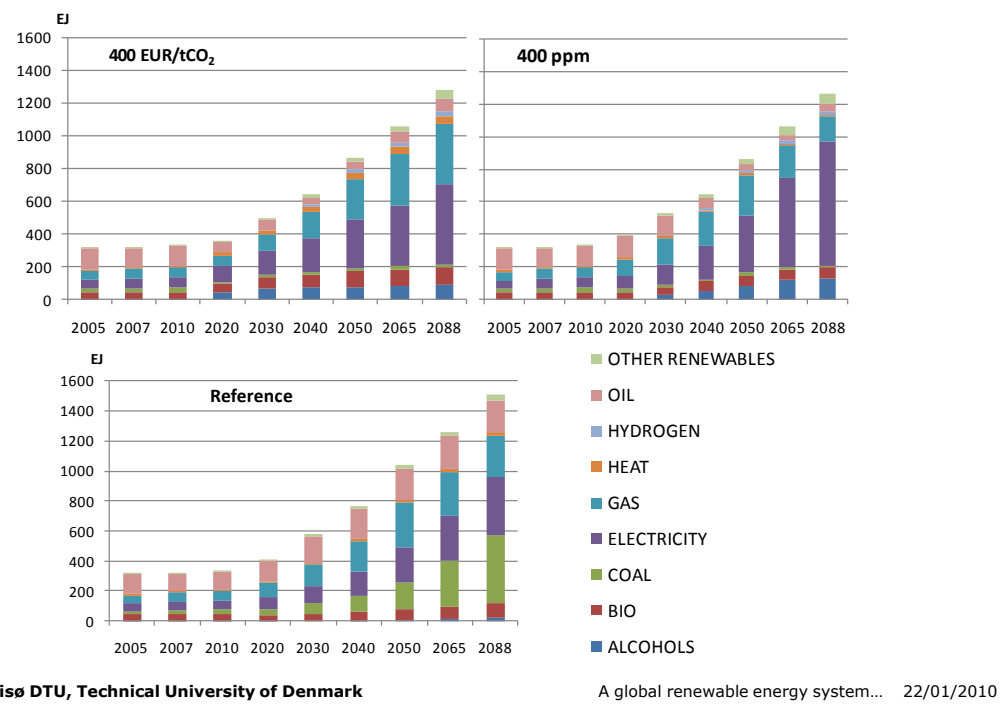




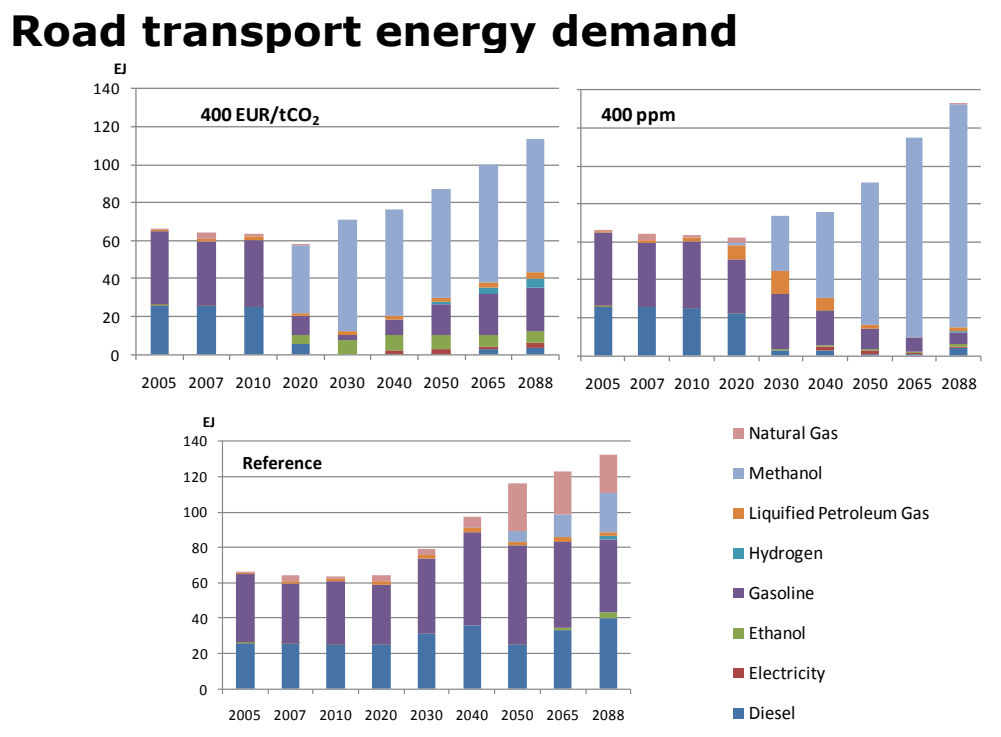

\section{Fossil resources and cumulative use in $\mathbf{2 1 0 0}$}

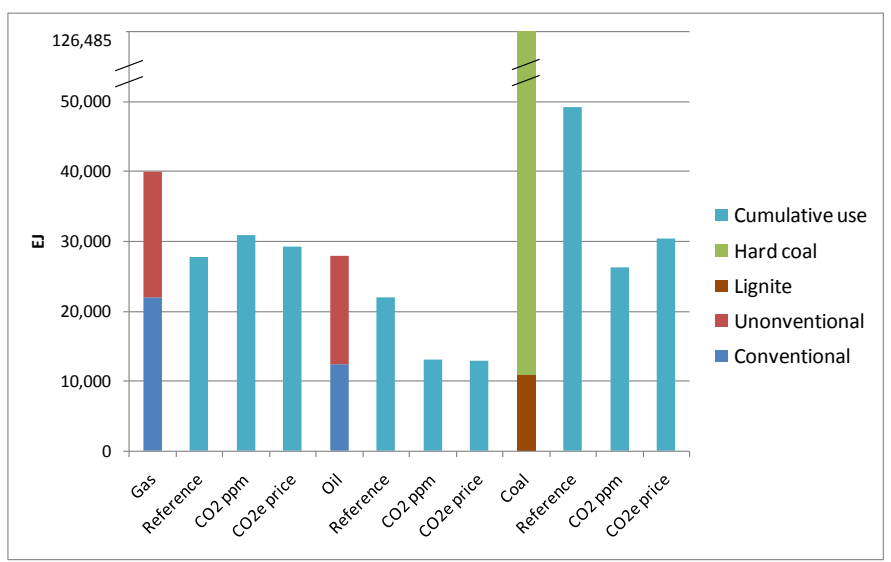

Source: "Review of resources and trade of fossil energy resources in the TIAM model" (ETSAP) and own calculations. 


\section{Renewable resource utilisation (2050)}

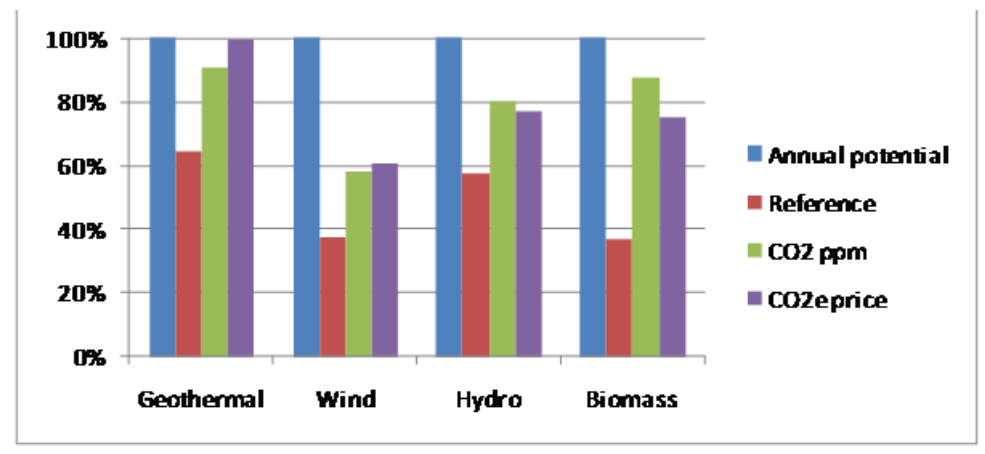

\section{Conclusions}

- A $100 \%$ renewable energy system was not achieved

- The system went (very) close to the resource limits

- Important to refine renewable resource potentials if a global $100 \%$ renewable energy system is sought

- Harder to reach a $100 \%$ renewable system with the high economic growth scenario used in the current TIAM version

- Given the large efficiency potentials that exist now and in the future, energy efficiency is an important area where the databases for TIAM and thereby the investment possibilities for the model probably could be improved 


\section{Discussion}

- More detailed mapping of resource potentials will improve the model, including consideration of local conditions

- Plan: to increase level of detail for renewable resources in the TIAM database for each of the 15 regions

- Example: Wind power potential in Denmark and assumed production cost of 1 MWh electricity

\begin{tabular}{|l|c|c|}
\hline Placement & Potential PJ/year & $\$ / M W h$ \\
\hline Onshore & 33 & 80 \\
\hline Offshore - near coast & 144 & 90 \\
\hline Offshore - far from coast & 1040 & 130 \\
\hline
\end{tabular}

- Particularly problematic: biomass.

- Complex link between biomass for energy, food and fodder

- Varying yields

- Improved database through detailed local studies

\section{The way forward...}

- Internally financed project on renewable potentials and integration, with focus on India and China

- Applications:

- InterAirPAC - Interaction of Air Pollution, Atmospheric Chemistry and Climate Change

- TIAM for global scenarios

- Development of an integrated framework and model system for health impact assessment of GHG reduction policies in urban areas of Europe and China

- TIAM for global scenarios and policy analysis 


\section{THANK YOU FOR YOUR ATTENTION!}

Olexandr Balyk: obal@risoe.dtu.dk

T. Helene Ystanes Føyn: tufn@risoe.dtu.dk

DTU Climate Centre:

http://www.dtu.dk/centre/Klimacenter/english.aspx 